\title{
Association between the orientation received during hospitalization and the occurrence of wound healing
}

\author{
Associação entre a orientação recebida durante a internação e a ocorrência de cicatrização de feridas \\ Relación entre la orientación recibida durante la internación y la ocurrencia de cicatrización de heridas
}

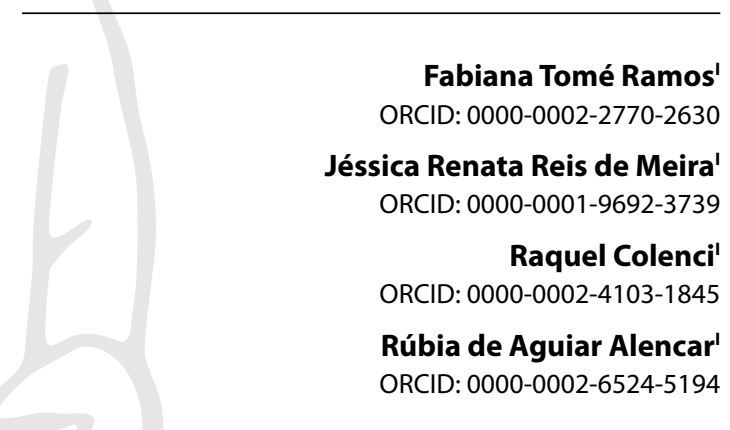

'Universidade Estadual Paulista. Botucatu, São Paulo, Brazil.

How to cite this article:

Ramos FT, Meira JRR, Colenci R, Alencar RA. Association between the orientation received during hospitalization and the occurrence of wound healing. Rev Bras Enferm. 2021;74(2):e20190647. https://doi.org/10.1590/0034-7167-2019-0647

Corresponding author:

Fabiana Tomé Ramos

fabiana-tr@hotmail.com

EDITOR IN CHIEF: Antonio José de Almeida Filho ASSOCIATE EDITOR: Andrea Bernardes

Submission: 12-04-2019Ａpproval: 12-11-2020

\begin{abstract}
Objectives: to assess whether there is an association between the orientation received during hospitalization and the occurrence of wound healing from the patient's perspective after hospital discharge. Methods: concurrent cohort, with 180-day follow-up, held in Dermatology Ward. A total of 62 patients with wounds requiring care after discharge were evaluated between July 2015 and November 2016. Information about the orientation was obtained by phone call between 7 and 10,60, 120 and 180 days after discharge. Results: the older the patient, the lower the chance of healing in up to ten days; and the longer the hospitalization, the lower the chance of healing. They received orientation in the high $90.3 \%$, while $87 \%$ understood the orientations. Conclusions: there was no association between the orientation received during hospitalization and the occurrence of wound healing from the patient's perspective after hospital discharge.
\end{abstract}

Descriptors: Orientation; Wounds and Injuries; Wound Healing; Health Education; Hospitalization.

\section{RESUMO}

Objetivos: avaliar se há associação entre a orientação recebida durante a internação e a ocorrência de cicatrização de feridas na perspectiva do paciente após a alta hospitalar. Métodos: coorte concorrente, com follow-up de 180 dias, realizada em Enfermaria de Dermatologia. Foram avaliados 62 pacientes com feridas que necessitaram de cuidado após alta, entre julho de 2015 e novembro de 2016. Informações sobre a orientação foram obtidas por ligação telefônica entre 7 e 10, 60, 120 e 180 dias após alta. Resultados: quanto maior a idade, menor a chance de cicatrização em até 10 dias; e quanto maior o tempo de internação, menor a chance de cicatrização. Receberam orientação na alta $90,3 \%$, enquanto $87 \%$ entenderam as orientações. Conclusões: não houve associação entre a orientação recebida durante a internação e a ocorrência de cicatrização de feridas na perspectiva do paciente após a alta hospitalar.

Descritores: Orientação; Ferimentos e Lesões; Cicatrização; Educação em Saúde; Hospitalização.

\section{RESUMEN}

Objetivos: evaluar si hay relación entre la orientación recibida durante la internación y la ocurrencia de cicatrización de heridas en la perspectiva del paciente después del alta hospitalaria. Métodos: corte concurrente, con follow-up de 180 días, realizada en Enfermería de Dermatología. Se evaluaron 62 pacientes con heridas que necesitaran de cuidado después del alta, entre julio de 2015 y noviembre de 2016. Informaciones sobre la orientación han sido obtenidas por llamada telefónica entre 7 y 10,60, 120 y 180 días después del alta. Resultados: cuanto mayor la edad, menor la chance de cicatrización en hasta 10 días; y cuanto mayor el tiempo de internación, menor la chance de cicatrización. Recibieran orientación en la alta $90,3 \%$, mientras $87 \%$ comprendieran las orientaciones. Conclusiones: no hubo relación entre la orientación recibida durante la internación y la ocurrencia de cicatrización de heridas en la perspectiva del paciente después del alta hospitalaria.

Descriptores: Orientación; Heridas y Traumatismos; Cicatrización de Heridas; Educación en Salud; Hospitalización. 


\section{INTRODUCTION}

Wounds are considered a public health problem in Brazil and worldwide, generating great economic impact to health systems ${ }^{(1-3)}$. They can reach individuals of various age groups; and, depending on the type of wound and its extensions, the treatment can be long ${ }^{(4)}$.

They are caused by the interruption of the continuity solution of the skin, due to trauma, intention, ischemia or pressure, and can have greater or lesser extensions ${ }^{(5)}$. The skin maintains the homeostasis of our internal environment and is considered an important protection barrier against external agents ${ }^{(6-7)}$. When an injury occurs, the body starts a sequence of events in order to restore this protection. Wound healing can be divided into four phases: hemostasis, inflammation, proliferation and repair ${ }^{(7)}$.

Acute wounds are considered to be those that follow a process of repair within the expected period and without complications. However, in chronic wounds, the repair process has been interrupted for some reason; and the repair, postponed ${ }^{(8)}$. It should be noted that pre-existing diseases, chronic, malnutrition, food deficit, advanced age, smoking, obesity, among other factors, may interfere in the wound healing process ${ }^{(9)}$.

The patient who has a wound requires daily assessment by the professionals in order to ensure care and prevention of complications. However, the long period of hospitalization can impair the healing process, leading to infections, deep vein thrombosis, increased hospital costs, in addition to the psychosocial impact ${ }^{(10)}$.

In order for the professional to be able to carry out an integral care and adequate orientation of the wound, several points must be evaluated besides the wound itself and its pathophysiology, such as the quality of life, clinical and sociodemographic aspects $^{(4,11)}$. Nursing has a fundamental role to meet the needs of each patient ${ }^{(12)}$ and, considering the objectives of the nursing assistance, it is evident the performance of the self-care, that makes possible the stimulation of the active participation of the patient in its treatment, when sharing with the nurse the responsibility in the implementation of the assistance and in the results ${ }^{(13)}$.

According to the Ministry of Health, the hospital is a "health establishment designed to provide medical and hospital care to inpatients"(14). Faced with such a definition, the individual who needs hospitalization will have the need to adapt to a new routine, because each patient will face hospitalization differently ${ }^{(9)}$. Many times, it is necessary for the patient to share the room with other people, having to wait for the medication, bath time, food, dressing, visit time, among others, which compromises his individuality and autonomy ${ }^{(15)}$. This commitment may be aggravated by the existence of wounds.

In this context, it is believed that in order to face the challenges of caring for people with wounds, it is necessary to identify factors that may influence them to become more involved in selfcare. In 1985, Dorothy Orem defined self-care as "the practice of activities that the individual initiates and performs for his/ her own benefit in order to maintain life, health and well-being. This model of nursing values the responsibility of the individual with the health, contributing in specific way in the integrity, the functions and the human development ${ }^{(16)}$.

It is also worth mentioning that, besides encouraging selfcare, health education is part of the nurse's job, being one of the main responsible for this teaching learning process ${ }^{(17)}$; in which, however, the entire team must be involved in order for full care to occur ${ }^{(18)}$.

According to the World Health Organization (WHO), therapeutic adherence is "the degree of correspondence and agreement of the patient with the recommendations of the doctor or other health professional regarding medication intake, diet follow-up and changes in living habits"(19). Thus, the recommendations of health teams to be followed by patients require their active participation in their health-disease process.

In this scenario, there are discharge guidelines that seek to ensure the continuity of care performed in the hospital environment, as well as contribute to a good recovery of the patient, being able to prevent complications and avoid readmissions ${ }^{(20)}$. In addition, discharge planning aims to reduce costs and improve the patient's wound healing process ${ }^{(21)}$.

Regarding the present investigation, after evidencing the readmission of some patients with leg ulcers in the Dermatology Infirmary, the undergraduate students who were in practical activity in this sector began to question the reasons for readmission. After talking to the patients, the students observed that they had little information about wound care and that they rarely recognized the provision of guidance by health professionals on wound care during hospitalization and/or at hospital discharge.

Therefore, in view of the scarcity of studies that approach the orientation of hospital discharge in the care of wounds and their healing and considering that, besides verifying the occurrence of the orientation, it was also necessary to know about wound healing after hospitalization, and this study is justified by the need to verify if the provision of orientation on wound care interferes in the occurrence of healing in the patient's perspective.

\section{OBJECTIVES}

To evaluate if there is an association between the orientation received during hospitalization and the occurrence of wound healing from the patient's perspective after discharge from hospital.

\section{METHODS}

\section{Ethical aspects}

The study was approved by the Research Ethics Committee of the Botucatu Medical School - Unesp and followed the ethical recommendations of the National Health Council, according to Resolution NHC/MS No. 466/12.

\section{Design, period and study location}

It is a competitor cohort study, with 180 days follow-up, guided by the STROBE tool ${ }^{(22)}$. The recruitment period for the survey subjects was from July 2015 to May 2016, and the data collection was completed on November 25, 2016.

The cohort was included in the Dermatology Infirmary of a public hospital located in a city of the interior of the state of São Paulo. 


\section{Population or sample; inclusion and exclusion criteria}

The population consisted of patients admitted to the Dermatology Ward who would need wound care after discharge from hospital.

The inclusion criteria of the study participants were: patients over 18 years of age admitted to the Dermatology Ward with wounds resulting from surgical scars, ulcers, pressure lesions, traumatic injuries, infectious and inflammatory wounds that needed care/ treatment after discharge from hospital. The exclusion criterion was: do not accept to participate in the study.

In the established period, there were 552 patients admitted to the Dermatology Infirmary, 71 of which met the inclusion criteria, were invited to participate in the research while they were hospitalized, and there was no refusal. However, during the development of the research, nine losses occurred, four died after discharge, four had their wounds healed during hospitalization and one patient escaped from the hospital. Thus, the sample was composed by 62 patients as detailed in Figure 1 .

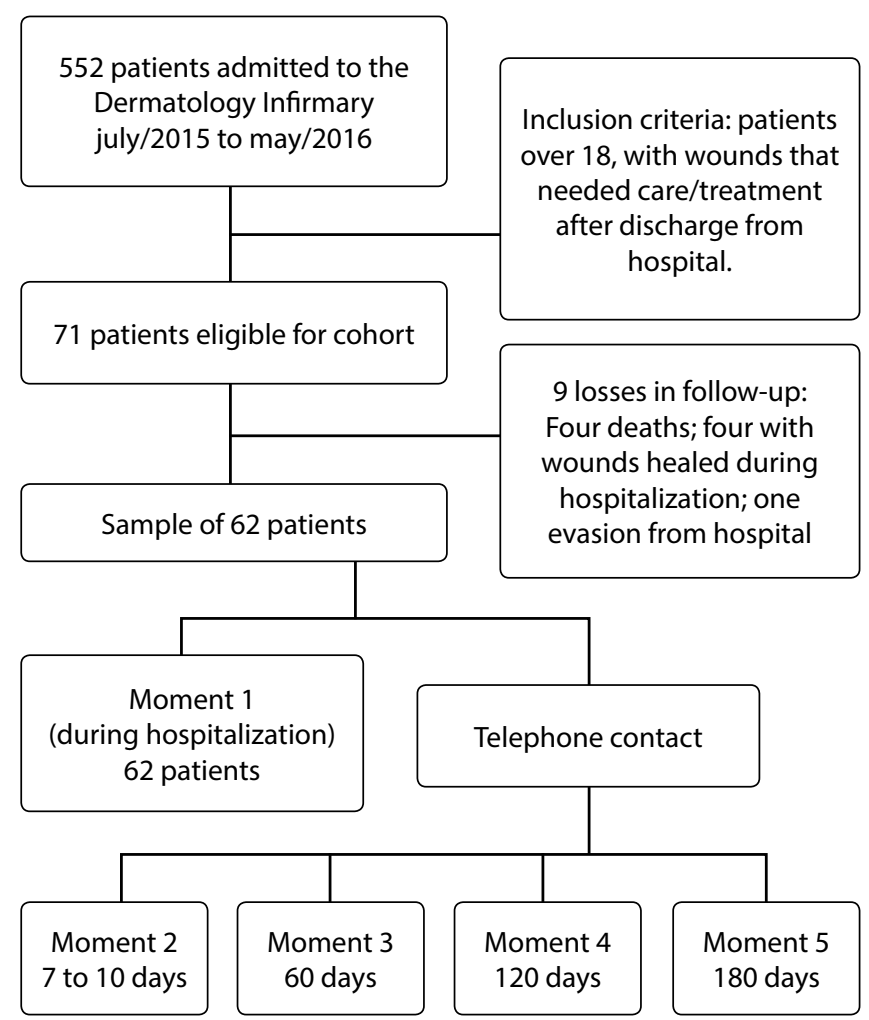

Figure 1 - Recruitment flowchart and study follow-up

\section{Study protocol}

During hospitalization, the researchers approached the patient who could be part of the study, provided the clarification of the objectives of the research and requested the signature of the Free and Informed Consent Term, if the patient accepted to participate in the research.

The data collection took place during five different moments, the first being during hospitalization, while the other four moments happened after hospital discharge, by means of phone calls, between seven and 10 days, 60 days, 120 days and 180 days after hospital discharge.

To identify the occurrence of the orientation given by health professionals who worked in the Dermatology Ward (nurse, technicians and nursing assistants, residents and doctors) during the period of hospitalization of patients until discharge from hospital, we used an instrument that was built by specialist nurses specifically for this study. The instrument was evaluated by members of the Wound Dressing Committee of the study hospital and was considered adequate to answer the research question. This committee recommended the creation of the Orientation Score (OS).

The OS varies from 0 to 5 points and considers that, the higher the score, the greater is the access to orientation performed by some member of the health team to the patient, that is, the exposure is a numerical variable that represents the receipt of orientation. The OS points were calculated based on the sum of the associated points between four items: 1 - During the period in which you were hospitalized, did you receive explanations about how the curative should be done? No (0 point), Yes (1 point); 2 - During the period that you were interned, did you have the opportunity to practice how the dressing should be done, doing the dressing itself? No (0 point), Yes (1 point); 3 - During the hospital discharge, did you receive orientation to take care of the dressing? No (0 point). Yes, the orientation was given only verbally (1 point). Yes, the orientation was given only on paper (1 point). Yes, the orientation was given verbally and on paper (2 points); and 4 - On the day you received the orientation at hospital discharge, did you understand them? No (0 point), Yes (1 point).

Sociodemographic variables such as age, gender, presence of partner (yes/no), schooling (illiterate, incomplete elementary school, incomplete high school, complete high school and college), living with someone (yes/no), family income (in minimum wages); and clinical variables, such as type of wound (surgical scar/ulcers/ traumatic pressure/ infectious and inflammatory wound), healing time (days) and length of stay (days).

\section{Analysis of results and statistics}

The binary outcomes considered were: occurrence of wound healing between 7 and 10 days (M2), up to 60 days (M3), up to 120 days (M4) and up to 180 days (M5).

For the purpose of estimating the power of the test, assuming simple random sampling, type l error of 0.05 , equal proportions between binary exposures and fixing the "surgical scar" exposure, it was estimated that the sample size of the study allowed tests with power above $80 \%$.

The association between the independent variable "score of orientation received" and the healing outcomes at each of the observed moments was analyzed by adjusting multiple logistic regression models in two steps. In the first step, confounding variables were identified by adjusting a multiple regression model using semi-automatic backward selection, which consists of an algorithm oriented to exclude variables that explain little about the outcome. In this process, intermediate models are discarded, leaving only the final model with the minimum necessary of confounding variables, thus respecting the principle of parsimony. In the second step, a multiple logistic regression model was adjusted again, 
now containing, in its deterministic component, the independent variable that was the orientation score, besides the confounding variables that were important in the first step. In the final model, the associations were considered statistically significant if $\mathrm{p}<$ 0.05. The analysis was done with the SPSS software, version 21.0.

\section{RESULTS}

The sample consisted of 62 patients, most of them male, living with partner, with an average age of 60.7 years, low level of education, since $54.9 \%$ did not complete elementary school, which is reflected in the average family salary of 1.7 minimum wages (Table 1).

Table 2 shows that, from the patient's perspective, surgical wounds had shorter healing time compared to inflammatory wounds and pressure lesions, which did not heal at the end of 180 days.

The OS varied from 0 to 5 points, being an average value of 2.38 ( $S D \pm 1.09$ ). It is emphasized that $61.3 \%$ did not receive orientation on how to do the dressing during hospitalization and $96.8 \%$ did not have the opportunity to practice it during hospitalization. The majority of $56(90.3 \%)$ patients received verbal or written orientation on how to do the dressing. However, 8 (13\%) did not understand the orientations received (Table 3 ).

Table 1 - Distribution of patients according to sociodemographic characteristics, Botucatu, São Paulo, Brazil, 2015-2016

\begin{tabular}{lc}
\hline Variables & $\mathbf{n}(\%)$ \\
\hline Sex & \\
$\quad$ Female & $28(45.1)$ \\
$\quad$ Male & $34(54.9)$ \\
Age & $60.7(18-89)^{*}$ \\
Has a partner & \\
$\quad$ Yes & $47(76.0)$ \\
No & $15(24.0)$ \\
Lives with family & \\
Yes & $58(93.5)$ \\
No & $4(6.5)$ \\
Education & \\
$\quad$ Illiterate & $8(12.9)$ \\
Incomplete elementary school & $26(42)$ \\
Complete Elementary School & $17(27.4)$ \\
Incomplete High School & $1(1.6)$ \\
Complete High School & $8(12.9)$ \\
$\quad$ Higher education & $2(3.2)$ \\
Family income & \\
$\quad$ No. of minimum wages per family & $1.7(1-5)^{*}$ \\
\hline Note: ${ }^{*}$ Mean (minimum-maximum). &
\end{tabular}

Table 2 - Distribution of wound types according to length of stay and post-discharge healing of patients in a public hospital Dermatology Ward, Botucatu, São Paulo, Brazil, 20152016

\begin{tabular}{lcccccccc}
\hline Wound type & $\mathbf{n}$ (\%) & $\begin{array}{c}\text { Time of } \\
\text { hospitalization* } \\
\text { Average } \\
\text { (Min.-max.) }\end{array}$ & $\begin{array}{c}\text { M2 } \\
\mathbf{n}(\%)\end{array}$ & $\begin{array}{c}\text { M3 } \\
\mathbf{n ( \% )}\end{array}$ & $\begin{array}{c}\text { M4 } \\
\mathbf{n}(\%)\end{array}$ & $\begin{array}{c}\text { M5 } \\
\mathbf{n ( \% )}\end{array}$ & $\begin{array}{c}\text { Not healed } \\
\text { at 180 days } \\
\mathbf{n}(\%)\end{array}$ \\
\hline Surgical & $34(54.8)$ & $19.6(2-133)$ & $19(55.9)$ & $12(35.3)$ & $0(0.0)$ & $0(0.0)$ & $3(8.8)$ \\
Ulcers & $19(30.6)$ & $23.8(6-54)$ & $0(0.0)$ & $4(21.0)$ & $4(21.0)$ & $2(10.6)$ & $9(47.4)$ \\
Infectious & $4(6.4)$ & $33.2(16-75)$ & $0(0.0)$ & $2(50.0)$ & $0(0.0)$ & $0(0.0)$ & $2(50.0)$ \\
Inflammatory & $2(3.2)$ & $36.5(21-52)$ & $0(0.0)$ & $0(0.0)$ & $0(0.0)$ & $0(0.0)$ & $2(100.0)$ \\
Pressure Ulcer & $2(3.2)$ & $24.5(12-37)$ & $0(0.0)$ & $0(0.0)$ & $0(0.0)$ & $0(0.0)$ & $2(100.0)$ \\
Traumatic & $1(1.6)$ & 9 & $0(0.0)$ & $1(100.0)$ & $0(0.0)$ & $0(0.0)$ & $0(0.0)$ \\
\hline Note: *Calculated in days. & & & & & & &
\end{tabular}

Table 3 - Orientation score given by health professionals who worked in the Dermatology Ward to patients during the period of hospitalization until discharge, Botucatu, São Paulo, Brazil, 20152016

\begin{tabular}{lc}
\hline Orientation Score (OS) & $\mathbf{n}(\%)$ \\
\hline $\begin{array}{l}\text { They received orientation on how to dress the wound } \\
\text { during hospitalization }\end{array}$ & \\
$\quad$ Yes & $24(38.7)$ \\
No & $38(61.3)$ \\
They had the opportunity to practice it during & \\
hospitalization & $2(3.2)$ \\
$\quad$ Yes & $60(96.8)$ \\
No & \\
They received orientation at hospital discharge & \\
$\quad$ Yes & $66(90.3)$ \\
No & $6(9.7)$ \\
Have understood the guidelines received & \\
Yes & $54(87)$ \\
No & $8(13)$ \\
\hline
\end{tabular}

Table 4 - Distribution, by multiple logistic regressions, of factors associated with healing in four moments after discharge from hospital of patients admitted to the Dermatology Infirmary, Botucatu, São Paulo, Brazil, 2015-2016

\begin{tabular}{lll}
\hline $\begin{array}{l}\text { Days of hospitaliza- } \\
\text { tion }\end{array}$ & Associated Factors & $\begin{array}{c}\text { OR* }^{*}(\mathbf{C l 9 5 \% * * ) :} \\
\boldsymbol{p} \text { value }\end{array}$ \\
\hline Up to 10 days & Age & $0.96(0.93-0.99): 0.007$ \\
& Quality of orientation & $0.72(042-1.25): 0.248$ \\
Up to 60 days & Days of hospitalization & $0.96(0.93-0.99): 0.027$ \\
& Quality of orientation & $0.63(0.35-1.16): 0.138$ \\
Up to 120 days & Days of hospitalization & $0.96(0.93-0.99): 0.013$ \\
& Quality of orientation & $0.98(0.48-2.00): 0.962$ \\
Up to 180 days & Days of hospitalization & $0.77(0.42-1.44): 0.420$ \\
& Quality of orientation & $0.96(0.93-0.99): 0.020$ \\
\hline
\end{tabular}

In Table 4, it is observed that there was no association of the orientation received during hospitalization with the occurrence of wound healing from the patient's perspective. However, it was observed that the older the patient, the lower the chance of healing in up to ten days; and the longer the hospitalization period, the lower the chance of healing.

\section{DISCUSSION}

In this cohort study, it was possible to identify that the older the age, the lower the chance of healing in up to ten days; and the longer the length of hospitalization, the lower the chance of healing. However, there was no association between the orientation received during hospitalization and the occurrence of wound healing after discharge from the patient's perspective.

As an intervention strategy, since 1970, the telephone has been used for the follow-up of patients with chronic diseases, conducting screening or health counseling. Thus, several benefits of its use are pointed out, such as the speed of access of the patient to the health professional and the possibility of increasing the 
frequency of contacts. In nursing, this means of communication appears as a powerful tool for integral care, which expands the action in health, representing an evolution before the traditional care ${ }^{(23)}$.

The magnitude and relevance of the study can be evidenced by the large number of patients with surgical wounds, ulcers, pressure lesions, traumatic injuries, infectious and inflammatory wounds, which often result from the living and working conditions of individuals. In this sense, social, economic, racial, cultural, psychological and behavioral factors are considered as social determinants of health and influence the population's health worsening ${ }^{(24)}$. This fact is observed in this study, when it was found that most individuals have a low level of education and income, which in turn can make it difficult to understand the guidance received by health professionals on wound care.

Regarding the healing process, there are factors that help or hinder it. The variable "age" presented a negative correlation with the chance of wound healing, which may have as justification the physiological aging of the skin. Such aspect interferes in the functions of protection, thermoregulation, sensibility and metabolism, leading to the fragility of the skin and diminishing the capacity to act as a protection barrier ${ }^{(25)}$. Although diseases and disabilities are not necessarily related to the aging process, it is observed that chronic degenerative diseases are more frequent among the elderly ${ }^{(26)}$.

Another factor that affects healing is prolonged hospitalization, because the patient is more susceptible to infections, which can prolong their hospitalization ${ }^{(27)}$. This event is observed in this study: the longer the hospitalization, the lower the chance of wound healing.

In addition, it is important to stress that nutrition is essential for the prevention and treatment of wounds. During the treatment and healing process, nutritional deficiencies and malnutrition can interfere with proper treatment and delay the healing process ${ }^{(28)}$.

In view of the above, it is evident that there are numerous factors that influence the wound healing process: systemic clinical conditions, control of etiological factors, conditions for wound management, topical therapies used, among others. It is also worth mentioning that, besides the fact that the wounds present different healing processes and times, the adherence to self-care with them should be considered ${ }^{(24-28)}$.

Thus, it is understood that the factors mentioned are intervening variables in the wound healing process - variables that can be used in the analysis. However, it is emphasized that the aim of this study was restricted to assessing whether there was orientation during hospitalization and whether the instruction influenced the occurrence of wound healing from the patient's perspective after discharge.

In the context of the improvement of this care, in 2013, the Ministry of Health instituted the National Patient Safety Program (NPSP), through the publication of Ordinance GM No. 529, with the purpose of contributing to the qualification of health care in all establishments in the national territory. In 2017, the technical note on safe practices for the prevention of pressure injuries aimed at providing guidance on general measures for surveillance and monitoring of adverse events related to care ${ }^{(29)}$.

In line with these measures and in order to ensure continuity of care at home and avoid future hospitalizations, it is necessary that discharge from hospital be planned during hospitalization, ensuring guidance on wound care and understanding of both patient and family members ${ }^{(30)}$. It should be noted that, in this study, the presence or absence of a companion at the time of hospital discharge was not questioned.

It is understood that a personalized plan for each patient leaving a hospital can ensure that he leaves the hospital at an appropriate time to develop his care and that, with proper notification, post discharge services are organized. As evidence of this, a systematic review study shows that an individualized discharge plan entails a small reduction in the length of hospital stay, reduces the risk of re-entry by three months for older people, and leads to greater satisfaction with health care for patients and professionals. However, it also highlights that there is little evidence that this plan reduces costs for health services ${ }^{(21)}$.

In addition to hospital discharge, it is necessary to overcome the weaknesses of the model of care. Therefore, the Ministry of Health has redirected actions and services through the Health Care Networks ( $\mathrm{HCN})$, which have the guiding and organizing principle of health practices and seek for integral assistance. The main objective of HCN is the "continuous articulation of preventive and curative actions and services, individual and collective, required for each case in all levels of system complexity"(31).

However, even counting on $\mathrm{HCN}$, there are still difficulties in communication between Primary Care health professionals and high complexity, with a disarticulation of the service network due to the fragility of the counter-reference, which can interfere negatively in the continuity of patient care ${ }^{(32)}$.

In clinical practice, it has been observed that discharge instructions are given at the time of the patient's discharge and are not carried out during the period of hospitalization ${ }^{(33)}$. This data was corroborated in this study, because the majority did not receive orientation on how to do the dressing, and only $3.2 \%$ had the opportunity to practice the dressing during hospitalization.

Thus, several pieces of information are provided at once at the time of hospital discharge, generating subsequent doubts, especially if these guidelines were not given in writing, which makes it difficult to understand and favors the occurrence of errors ${ }^{(33)}$.

Health services from other countries, such as Canada, Spain and Portugal, focus on the role of the "liaison nurse", which aims to ensure continuity of care between the hospital and other services. Through this, the nurse identifies the hospitalized patients who will need to continue care after discharge, assuming the function of performing the articulation/counter-reference between the points of the $\mathrm{HCN}^{(32)}$.

Still on the discharge plan, the importance of the inter-professional work that should cover all the professionals involved during the internment, overcoming the fragmentation of the health care, is highlighted. Only in this way would discussions be made about the decision making of the care, according to the patient's reality ${ }^{(33)}$.

It is emphasized that inter-professional education is learning in an interactive way, so that professionals can work together collaboratively, articulating the specific activities of each professional area. Thus, inter-professional education is extremely important for the improvement of access and quality in $\mathrm{HCN}^{(34)}$. 


\section{Study limitations}

As it is an applied research, there is a lack of information about the OS accuracy and precision, since the score was created specifically to evaluate if there is an association between the orientation received during hospitalization and the occurrence of wound healing from the patient's perspective after discharge; and it was used to solve a practical issue of the moment. However, it should be noted that in elaborating, together with professionals specialized in the subject addressed, the OS questions, sufficient clarity was taken into account to minimize the risk of error in interpretation and, in turn, minimize the risk of systematic error of information or lack of accuracy of the score. Another point to be considered is that the researcher who carried out the collection was not part of the team of the Dermatology Ward.

It was observed that the OS points were below average, and this shows that few patients had access to orientation during hospitalization and/or at discharge. It is believed in future studies that the increase in the OS points will identify possible association with wound healing.

Moreover, the study did not consider the intervening variables, cited in the discussion, that could interfere in the wound healing process, because for such an analysis it would be necessary to considerably increase the number of participants. It should be noted that all 62 patients who participated in the study remained until the end of data collection. This fact is associated with the commitment of researchers and patients involved in this study. Thus, the good internal validity of the study is observed.

\section{Contributions to the Nursing area}

Among the contributions to the health care team that cares for the patient with a wound during hospitalization, it is evident that health professionals should pay attention to elderly patients with prolonged hospitalization, because the present study has shown that, in these two situations, there is less chance of wound healing.

\section{CONCLUSIONS}

There was no association between the orientation received during hospitalization, in relation to wound care, and the occurrence of healing after discharge from the patient's perspective. However, it was observed that the older the patient was, the lower was the chance of healing in up to ten days; and the longer the hospital stay, the lower was the chance of healing.

It is important to develop other studies on the quality of guidance provided at hospital discharge, as well as on the analysis of the numerous factors that may interfere with the wound healing process when the patient returns home.

\section{REFERENCES}

1. Azevedo IC, Costa RKS, Ferreira Jr MA. Perfil da produção científica da enfermagem nacional sobre feridas. Rev Cubana Enferm [Internet]. 2018 [cited 2020 Aug 18];34(1). Available from: http://www.revenfermeria.sld.cu/index.php/enf/article/view/1440/339

2. Barros MPL, Ferreria PJO, Maniva SCFJ, Holanda RE. Caracterização de feridas crônicas de um grupo de pacientes acompanhados no domicílio. Rev Interdisc [Internet]. 2016 [cited 2020 Aug 18];9(3):1-11. Available from: https://revistainterdisciplinar.uninovafapi.edu.br/index.php revinter/article/ view/926

3. Macedo EAB, Freitas CCS, Dionisio AJ, Torres GV. Knowledge of the care of wounded patients: evidence of validity of an instrument. Rev Bras Enferm. 2019;72(6):1562-70. https:// doi.org/10.1590/0034-7167-2018-0643

4. Ribeiro GSC, Cavalcante TB, Santos KCB, Feitosa AHC, Silva BRS, Santos GL. Pacientes internados com feridas crônicas: um enfoque na qualidade de vida. Enferm Foco 2019;10(2):70-5. https://doi.org/10.21675/2357-707X.2019.v10.n2.1740

5. Cesaretti IUR. Processo fisiológico de cicatrização da ferida. Pelle Sana 1998;2:10-2.

6. D Doughty. Emory University Wound, Ostomy, and Continence Nursing Education Center's wound core curriculum, Emory University WOCNEC, Atlanta (GA); 2016. pp. 1-312

7. Li J, Chen J, Kirsner R. Pathophysiology of Acute Wound Healing. Clin Dermatol. 2007;25(1):9-18. https://doi.org/10.1016/j. clindermatol.2006.09.007

8. Lazarus G, Cooper D, Knighton D, Margolis D, Pecoraro R, Rodeheaver G. Definitions and guidelines for assessment of wounds and evaluation of healing. Arch Dermatol. 1994;130:489-93.

9. Campos ACL, Borges-Branco A, Groth AK. Wound healing. ABCD, Arq Bras Cir Dig. 2007;20(1):51-8. https://doi.org/10.1590/S0102-67202007000100010

10. Lima RVK, Coltro PS, Farina JJA. Negative pressure therapy for the treatment of complex wounds. Rev Col Bras Cir. 2017;44(1):81-93. https:// doi.org/10.1590/0100-69912017001001.

11. Lucena PLC, Pereira MA, Santana AP. Evidências científicas sobre intervenções para pessoas com feridas em cuidados paliativos: revisão de escopo. Rev Pesqui: Cuid Fundam.2020;12:730-6. https://doi.org/10.9789/2175-5361.rpcfo.v12.9467

12. Rangel RF, Backes DS, Ilha S, Zamberlan C, Siqueira HCH, Costenaro RGS. Formação para o cuidado integral: percepção de docentes e discentes de Enfermagem. Rev Pesqui: Cuid Fundam[Internet]. 2017 [cited 2017 Sep 19];9(2):488-94. Available from: http://www.seer.unirio. br/index.php/cuidadofundamental/article/view/5450/pdf

13. Santos AAP, Monteiro EKR, Póvoas FTX, Lima LPM, Silva, FCL. O papel do enfermeiro na promoção do envelhecimento saudável. Espaç Saúde. 2014;15(2):21-8. https://doi.org/10.22421/1517-7130.2014v15n2p21 
14. Ministério da Saúde (BR). Glossário do Ministério da Saúde: projeto de terminologia em saúde [Internet]. 2004 [cited 2018 Sep 18]. Available from: http://bvsms.saude.gov.br/bvs/publicacoes/glossario_ms.pdf

15. Florisbal GS, Donelli MSD. Revivendo perdas: um estudo com pacientes hospitalizados em uma unidade de internação. Rev SBPH [Internet]. 2017 [cited 2018 Aug 25];20(1):75-98. Available from: http://pepsic.bvsalud.org/pdf/rsbph/v20n1/v20n1a06.pdf

16. Orem DE. Nursing: concepts of practice. 2. ed. New York: McGrau-Hill, 1980. Ch.3, p. 35-54: Nursing and self-care.

17. Rigon AG, Neves ET. Educação em saúde e a atuação de enfermagem no contexto de unidades de internação hospitalar: o que tem sido ou há para ser dito? Texto Contexto Enferm. 2011;20(4):812-7. https://doi.org/10.1590/S0104-07072011000400022

18. Ferreira PBP. Educação para a saúde do paciente hospitalizado: um conceito com implicações para o cuidado de enfermagem [Tese] [Internet]. Rio de Janeiro: UFRJ; 2017[cited 2018 Aug 25];197 f. Available from: http://objdig.ufrj.br/51/teses/855923.pdf

19. Organização Mundial da Saúde (OMS). Cuidados inovadores para as condições crônicas: componentes estruturais de ação: relatório mundial. Brasília: OMS; 2003.

20. Cesar AM, Santos BL. Family caregivers' perception about a program of hospital discharge. Rev Bras Enferm. 2005;58(6):647-52. https://doi. org/10.1590/S0034-71672005000600004

21. Gonçalves-Bradley DC, Lannin NA, Clemson LM, Cameron ID, Shepperd S. Discharge planning from hospital. Cochrane Database System Rev. 2016;1:CD000313. https://doi.org/10.1002/14651858.CD000313.pub5

22. Malta M, Cardoso LO, Bastos FI, Magnanini MMF, Silva CMFP. STROBE initiative: guidelines on reporting observational studies. Rev Saúde Pública [Internet]. 2010[cited 2019 May 01];44(3):559-65. https://doi.org/10.1590/S0034-89102010000300021

23. Vasconcelos HCA, Freitas RWJF, Marinho NBP, Damasceno MMC, Araújo TL, Lima FET. Effectiveness of telephone interventions as a strategy for glycemic control: an integrative literature review. Texto Contexto Enferm. 2013;22(1):239-46. https://doi.org/10.1590/ S0104-07072013000100029

24. Ruiz ENF, Santos VF, Gerhardt TE. Mediations in health care under the perspective of the Theory of Gift: highlights of the health of a rural population. Physis. 2016;26(3):829-52. https://doi.org/10.1590/s0103-73312016000300007

25. Dantas RFB, Gouveia BLA, Albuquerque AM, Torquato IM, Ferreira, JA, Oliveira, SHS. Characterization of chronic injuries in the elderly assisted in the family health strategy. Rev Enferm UFPE. 2017;11(5). https://doi.org/10.5205/1981-8963-v11i5a23330p1835-1841-2017

26. Veiga B, Pereira RAB, Pereira AMVB, Nickel R. Evaluation of functionality and disability of older elderly outpatients using the WHODAS 2.0. Rev Bras Geriatr Gerontol. 2016;19(6):1015-21. https://doi.org/10.1590/1981-22562016019.150053

27. Villas Bôas PJF, Ruiz T. Occurrence of hospital infection among interned elderly in a university hospital. Rev Saúde Pública. 2004;38(3):372-8. https://doi.org/10.1590/S0034-89102004000300006

28. Sernekos LA. Nutritional treatment of pressure ulcers: what is the evidence? J Am Assoc Nurse Pract. 2013;25(6):281-8. https://doi. org/10.1002/2327-6924.12025

29. Ministério da Saúde (MS). Portaria $n^{\circ} 529$, de $1^{\circ}$ de abril de 2013. Institui o Programa Nacional de Segurança do Paciente (PNSP)[Internet]. Brasília; 2013 [cited 2018 Aug 20]. Available from: http://www.saude.mt.gov.br/upload/controle-infeccoes/pasta2/portaria-msgm-n-529de-01-04-2013.pdf

30. Izaias EM, Gomes Dellaroza MSG, Rossaneis MA, Belei RA. Custo e caracterização de infecção hospitalar em idosos. Ciênc Saúde Coletiva[Internet]. 2014 [cited 2017 Oct 15];19(8):3395-402. Available from: http: http://www.scielo.br/pdf/csc/v19n8/1413-8123csc-19-08-03395.pdf

31. Ministério da Saúde (MS). Portaria n 4.279, de 30 de dezembro de 2010. Estabelece diretrizes para a organização da Rede de Atenção à Saúde no âmbito do Sistema Único de Saúde (SUS) [Internet]. 2010 [cited 2016 May 12]. Available from: http://conselho.saude.gov.br/ ultimas_noticias/2011/img/07_jan_portaria4279_301210.pdf

32. Ribas EN, Bernardino ELLM, Poli NP, Aued GK, Silva CPC. Nurse liaison: a strategy for counter-referral. Rev Bras Enferm. 2018;71(Suppl-1):546-53. https://doi.org/10.1590/0034-7167-2017-0490

33. Martins ACS, Silva JG, Ferraz LM. Orientações de enfermagem na alta hospitalar: contribuições para o paciente e cuidadores. Convibra[Internet]. 2013 [cited 2017 Oct 19]. Available from: http://www.convibra.com.br/upload/paper/2013/70/2013_70_7857.pdf

34. Peduzzi M. The SUS is interprofessional. Interface. 2016;20(56):199-201. Available from: https://doi.org/10.1590/1807-57622015.0383 